Article

\title{
Margaret Cavendish, Feminist Ethics, and the Problem of Evil
}

\author{
Jill Graper Hernandez
}

Department of Philosophy, University of Texas at San Antonio, 10 Cocke Dr, San Antonio, TX 78249, USA;

jill.hernandez@utsa.edu

Received: 9 January 2018; Accepted: 10 April 2018; Published: 16 April 2018

\begin{abstract}
This paper argues that, although Margaret Cavendish's main philosophical contributions are not in philosophy of religion, she makes a case for a defense of God, in spite of the worst sorts of harms being present in the world. Her arguments about those harms actually presage those of contemporary feminist ethicists, which positions Cavendish's scholarship in a unique position: it makes a positive theodical contribution, by relying on evils that contemporary atheists think are the best evidence against the existence of God. To demonstrate that Cavendish's work should be considered as early modern feminist theodicy, this paper will briefly introduce the contemporary feminist worry about theodicy as a project, show that Cavendish shares the contemporary feminist view about situated evil, and argue that her theodicy aims for agreement about how to eradicate great moral evils while preserving free will-and so, carves out a space for future female philosophers of religion who aim to be agents of healing in the face of such evil.
\end{abstract}

Keywords: Margaret Cavendish; theodicy; problem of evil; free will; feminist ethics; atrocity paradigm; redemptive goods; divine justice

Contemporary feminist ethicists have argued that theodicy in analytic philosophy of religion is disconnected from the actual experiences of those who suffer, because theodicy primarily focuses on the logical necessity of evil. If theodicy cannot address the phenomenological impact of suffering, and distances the divine from culpability for the worst sorts of harm, theodicy also makes it difficult to account for human responsibility in bringing about preventable, culpable, atrocious harms. ${ }^{1}$ Fueling the feminist worry is that since the time of Leibniz (the author of the early modern period's Theodicy), only men have been taken seriously as contributors to the philosophical project of theodicy ${ }^{2}$, even though a number of female contemporaries of Leibniz made noteworthy strides in philosophy of religion, often writing in the guise of political treatises, or novels that emphasized civil rights.

There are two ways to rectify the problem: what counts as theodicy could be expanded to include unique arguments to demonstrate that the existence of a perfect God is compatible with evil; or, philosophy can expand the canon to include a diverse group of thinkers, who contributed to the theodical project despite not originally falling under the lofty appellation of "philosophers". This paper does both. It contends that the philosophical canon on theodicy should be widened to include Margaret Cavendish (1623-1673) as a philosopher of religion in the early modern period, although Cavendish does not write traditional philosophical treatises, does not have an orthodox conception of God, and does not set out to do theodicy. It also argues that our conception of theodicy should expand to incorporate Cavendish's arguments—she provides a traditional, free-will defense argument, but

1 The best examples are (Card 2002, 2010).

2 In philosophy, in the last twenty years, contemporary theists are reshaping the canon, including (Stump 2010; Adams 2006, 1999). 
also develops a participative redemptive theodicy, in which creative human agency can combat evil and transform society. Although it is true that, compared to contemporary theists, Cavendish provides a thin evaluation of divine culpability for evil, she also chooses to focus on positive human creation in the face of evil.

Since Cavendish's aim is not even secondarily the philosophy of religion, we might think that she does not set out to pursue a project in theodicy; nevertheless, she does defend God against blame for pernicious evil, even as she attempts to minimize political injustice, against women in particular. Her work presages, then, the contemporary feminist emphasis on situated suffering, but also provides distinctive contributions to philosophy of religion. To make the case for Cavendish's early modern feminist theodicy, this paper will briefly introduce the contemporary feminist worry about theodicy as a project, will show that Cavendish shares the contemporary feminist view about situated evil, and will argue that her theodicy aims for agreement about how to eradicate great moral evils while preserving free will—and so, carves out a space for future female philosophers of religion who aim to be agents of healing in the face of such evil. Cavendish provides a view that is both consistent with those of her male counterparts (since God does not interfere with the moral order as long as we have freedom) and trailblazing in the philosophy of religion. She uniquely advances theodicy in the early modern period by relying upon concrete moral evils as her point of departure towards an evaluation of redemptive responses to the problem of evil. ${ }^{3}$

\section{Cavendish, Morality, and Concrete Harms}

Recently, scholars have begun to make progress on including female scholars in the early modern period of philosophy as philosophers of religion. ${ }^{4}$ None, however, have yet focused exclusively on the scholarship of Cavendish as a philosopher of religion, working on the project of theodicy. One reason for this is Cavendish's own non-orthodox views of theology, and another must be that Cavendish contended that, whereas there is a supernatural being (Cavendish 1666, p. 17), the questions about the nature of God's existence were outside the scope of natural philosophy (Cavendish 1664a, pp. 3, 17). ${ }^{5}$ Jacquelyn Broad explains that, for Cavendish, "There is simply no need to posit the existence of immaterial substances, or the interference of God's spiritual intermediaries, in order to account for the life, motion, and organization of natural things." (Broad 2007, p. 499)

Theodicy faces two main critiques from contemporary feminist ethicists: first, theodicy utilizes a sense of "evil" that is fully divorced from atrocious harms (i.e., the sorts of harms that eliminate human dignity and individual identity); and second, the problem of evil does not even require the concept of "evil", since the very idea of God creating an imperfect world suffices to "cast major aspersions on the character of the supreme being" (Card 2002, pp. 12-13). The first worry faults theodicy for not adequately taking up the suffering that results from systems of oppression. Theodicies treat atrocious evils as a mere theoretical possibility (since it is necessary that humans have the free will to choose to commit evil, but it is contingent that those acts be performed). But treating evil as an abstract, logical category removes agency (whether human or divine) from the most egregious sorts of harm. Agency is required not only to hold someone responsible (who is to blame, after all, if the possibility of evil must be necessary?), but also to fully understand the impact of suffering on the world. Bat-Ami Bar On writes: "One stops witnessing when one abstracts so much and gets away from the phenomenological experience of the suffering of real people. Abstractness undermines the work on ... [which] a spectator depends in order to connect to embodied people in pain." (Bar On 2007, p. 196)

3 There are many more women in the long early modern period who contributed to the philosophical projects about evil or divine perfection who, for space issues, cannot be discussed here.

4 Hernandez (2016) focuses on Cavendish, as well as Catharine Macaulay, Mary Hays, Mary Astell, and Mary Wollstonecraft, but her treatment of Cavendish is underserved to make room for her discussion of transmuted goods.

5 Cavendish's work cited in this paper will include: [BW] (Cavendish [1666] 2003a); [ODS] (Cavendish [1666] 2003b); [OEP] (Cavendish 1666); [PB] (Cavendish 2000); [PF] (Cavendish 1653); [PL] (Cavendish 1664a); [SL] (Cavendish 1664b); [WO] (Cavendish 1655). 
The second level of contemporary critique against theodicy is a moral argument against God. Since humans who commit or allow atrocious evils could choose to do otherwise, and should choose to do otherwise, they are morally culpable for the harm brought about by them. Consider that citizens blame those in power for choosing not to prevent or limit suffering in the world when they are able. If human agents ought to be held responsible when they allow suffering they could have directly prevented, then all the more, God should be implicated by the presence of atrocious evil in the world. Theodicies, correlatively, fail to sufficiently account for God's perfection, since an all-good God would want to prevent atrocious evils, an all-knowing God would be able to see when and where they might occur, and an all-powerful God would be able to thwart those actions he sees and wants to prevent. ${ }^{6}$

However, for the positive impact contemporary feminists have had on focusing attention on foreseeable and preventable harm, the history of philosophy indicates that their views were presaged in important ways by female scholars in the early modern period, and Cavendish particularly. A focused treatment of her work reveals two shared traits between Cavendish and contemporary feminist ethicists: they both employ a concrete sense of evil, and the both reject traditional theodicy's messages of eschatological justice, which simply cannot be reconciled with the God of Christian Scripture (on Cavendish's view). If God is loving, God's created order would not mandate the suffering of the neediest, the most innocent, and the most oppressed.

On this hypothetical, Cavendish departs from contemporary ethicists. She believes that God is in fact loving, and spreads goodness on humanity, regardless of whether humans treat each other well:

In truth, Generosity and Humanity is like the Sun and the Air, for Humanity doth like the Air spread equally to all, it enters every where, and fills up all Vacuities; and Generosity like the Sun, shines every where, and on every Creature, although not at one Time, yet in such a Compass of Time as it hath strength and motion to extend it self; also his Benefits are General, he Disputes not Who or What deserves his Light or Heat, but knows his Light and Heat is Beneficial to all Creatures. (Cavendish 1664b, p. LVIII).

God does not quibble about who should be the beneficiaries of his goodness-all who live in the created order receive his gifts. Nature itself is so guided by physical laws that there cannot be disorder. Any perceived irregularities within creation are "just a reflection of our limited perspective and our parochial interests and concerns" (Cunning 2016, p. 172). If nature is governed by laws of creation, and humans are natural animals of that creation, then human action should also be rule-guided and in harmony with the divinely-inspired creation. ${ }^{7}$ Whatever divisions humans perpetuate within the created order are not flaws in the order itself, but a sign of disconnect between the rules and actions that are supposed to be governed by them. Rather, Cavendish writes, "those active Parts, being united into one Infinite body, cannot break Natures general Peace; for that which Man names War, Sickness, Sleep, Death, and the like, are but various particular actions of the onely matter; not, as your Author imagines, in a confusion, like Bullets, or such like things juggled together in a man's Hat, but very orderly and methodical ..." (Cavendish 1664a, p. 146). Human action, then, even when it results in negative consequences and suffering (war, sickness, sleep, death, etc.) cannot erode the natural order,

6 For a more in-depth analysis of the difficulty of concrete evil facing theodicy from a feminist ethical account see, for example, Hernandez (2016, chp. 1).

7 Although Cavendish believes God created this particular world (i.e., planet), she is not committed to the view that God created all of nature: "You will say, the Scripture doth teach us that, for it is not Six thousand years, when God created this World. I answer, the holy Scripture informs us onely of the Creation of this Visible World, but not of Nature and natural Matter; for I firmly believe according to the Word of God, that this World has been Created, as is described by Moses, but what is that to natural Matter? There may have been worlds before, as many are of the opinion that there have been men before Adam, and many amongst Divines do believe, that after the destruction of this World God will Create a new World again, as a new Heaven, and a new Earth; and if this be probable, or at least may be believed that there have been other worlds before this visible World? For nothing is impossible with God; and all this doth derogate nothing from the Honour and Glory of God, but rather increases his Divine Power" (Cavendish 1664a, p. 15). 
function, and unity of the world. Evil cannot overturn the orderly functioning of natural systems, but is instead evidence that sometimes humans make choices that run contrary to the guidance of morality.

Cavendish's emphasis that neither divine nor human interaction in the natural order can alter what occurs in nature has led some scholars to conclude that suffering and pain are natural consequences of human action within the natural order. It may seem, on their view, that Cavendish thinks that any attempt to attribute positive and negative value to the consequences of human action is empty. Cunning, for example, argues:

[Cavendish] is committed to the view that there is a necessary connection between a cause and its effect and that, in a plenum, there is no possible way for things to unfold other than they do. There is no possible reality outside of the bodies of the plenum; there is simply no grid. There are epistemic possibilities that are a reflection of the limited information that we have about our surroundings, but these (imagistic ideas) are just bodies in the plenum as well. Cavendish is committed to saying that there is only one way that things can be at any given moment, and so she will not ever assert that things should be a certain way, or that there are aims and purposes that the constituents of the plenum should take on apart from the ones that it in fact does. She instead holds that the plenum is simply as it is. We do employ normative terms like "good" and "bad", but these are just a reflection, from our own point-of-view, of how the plenum accommodates our interests and concerns. Different constituents of the plenum are competing with each other to maintain their respective proportions of motion, and that is that. This is a theme that recurs throughout the Cavendish corpus. As we have seen, she holds that strictly speaking there is no disorder or irregularity in nature; the decay and destruction of particular beings is just among the things that happen as creatures struggle to remain in existence. (Cunning 2016, p. 271).

Here, Cunning's argument moves from Cavendish's fact of necessary connection in the world to the emotive moral conclusion that normative judgments simply reflect personal preferences.

Cunning does admit, a bit later, that Cavendish appears to change her mind, at least on whether it is appropriate to label certain events as bad, especially when human action constrains the freedom of women and results in war (p. 273), but it seems that Cunning's inference from Cavendish's metaphysics to morality is inconsistent with several of Cavendish's other texts, which discuss concrete suffering. For instance, although Cavendish notoriously provides contrasting positions on metaphysics and epistemology across her writings, she does not equivocate about her strong sentiments against certain morally repugnant atrocities, such as civil war. She writes, in Sociable Letters:

... or else it proceeds from Unwise Government, where many Errours gather into a Mass, or Tumor of Evil, which Rises into Blisters of Discontents, and then Breaks out into Civil War; or else Heaven sends it to Punish the Sins of the People. Besides, it is to be observed, that Vices Increase in a Civil War, by reason Civil Government is in Disorder, Civil Magistrates Corrupted, Civil Laws Abolished, Civil Manners, and Decent Customs Banished, and in their Places is Ra|pine, Robbing, Stabbing, Treachery, and Falshood, all the Evil Passions and Debauch'd Appetites are let Loose, to take their Liberty. (Cavendish 1664b, CXX)

Evil passions and debauched appetites are let loose when disorder in government occurs and civil war breaks out. This disorder can then lead to multifarious, terrible wrongs (like rape, robbery, and murder). Some scholars, like Cunning, infer from Cavendish's writings about civil war that she "might be a bit conflicted", but that she "cannot hold that there is a fact of the matter to the effect that there is something bad about the death of an individual, even one's own self; nor can she hold that there is something literally bad about the destruction of an entire human society. When such things occur, they are just among the things that happen" (Cunning 2016, p. 273). Cunning is right that Cavendish believes it is metaphysically true that events occur within a created order, but it does not pragmatically or morally follow from this that these concrete harms are determined and inescapable. 
Neither should we infer that, for Cavendish, human agents are morally inculpable when they do not prevent the occurrence of evil, or do not minimize their harm when they are able.

It may be appropriate to read Cavendish's metaphysics as precluding real categories of "good" and "bad" in place of "what is", as suggested by Cunning, but the same reading cannot be made of Cavendish's views of ethics and justice-even if those views are more difficult to pin down. Cavendish actually says something quite like this in Sociable Letters, where she contrasts the difficulty of changing the physical world with the ability of education and habit to change the trajectory of human behavior:

for there is no Assurance or Certainty in the Effects or Influence of the Stars and Planets, there is more Assurance in the Educations, and Customs of Men, and Custom and Education hath Stronger Effects, for Custom and Education can Alter the Unaptness in Natural Capacities and Understandings, the Dull Dispositions, Froward, or Evil Passions of the Mind; also it oftentimes Tempers the Irregular Humours of the Body, and can Restrain the Unsatiable Appetites of the Body and Senses, and Long Custom Alters the Nature of Men. (Cavendish 1664b, CXXXVIII)

Here, Cavendish offers a striking contrast to Cunning's contention that there are no real moral categories. Cavendish actually presents an opposite view, that the moral has sway over the natural. If "custom" (i.e., habit and practice) and "education" can alter the inaptness, dullness, and evil passion of the mind, our actions can be morally better or worse, which makes us morally responsible to perform that best actions. Although not even the systematicity of nature (the "stars") can influence human nature, proper habituation, association, and education can yield an improved moral condition, and a better world, for us.

Deborah Boyle (2006), in contrast to Cunning, argues that we can find a pieced-together "consistent core" of political and ethical views in Cavendish's Orations (Cavendish [1666] 2003b). The orations address social issues and government, and are organized around shared themes of peace and stability (Cavendish [1666] 2003b, pp. 253-54). Perhaps most relevant to the question of concrete moral harms and goods, Boyle observes that Cavendish's moral project is grounded on identifying and eradicating immoral action-action that should be otherwise. Boyle observes:

In other texts, when Cavendish praises or blames individuals for their actions, she typically appeals to how their actions have increased or decreased peace. For example, she criticizes Cato for killing himself over a change of government; the new government was likely to make the country safer and more peaceful, Cavendish says, so someone who truly cared for peace and safety would have supported the change. (Boyle 2006, p. 254).

Justice in the public square comes directly from governmental order, but Cavendish appeals to others to behave in peaceful ways. If you believe in peace, you ought to act peaceably, since consistent thinking produces consistent action-moral thinking must result in bringing about moral states of affairs. The result is that Cavendish does not believe that all states of affairs are equal and determined. Instead, action is valuable based on whether its consequences are peaceful and positive, and whether an action ought to be performed depends in part on the extent to which it allows us to enjoy rights and peace: "Wherefore your best way is, to Submit and Obey, to be Content, to be Ruled, and not seek to Govern, to enjoy your Rights, and to revenge your Wrongs by Law and Justice, and not to make War and Confusion to destroy your selves" (Cavendish [1666] 2003b, p. 122). Of course, as a monarchist, Cavendish believes that we are most able to pursue action that produces the best states of affairs under a strong monarch. Such a leader is positioned to allow us to pursue peace, Cavendish thinks, and to avoid war (which can enslave, entrap, suppress rights, and create a false peace.) If there is a despotic government, or if a citizenry is morally base and confused, the predictable evils of war are likely to result. Cavendish's strong warning against the vices of war and her view that peace is the protector of virtue are powerfully present in her poem "A Dialogue Betwixt Peace and War": 
War.

Thou Flattering Peace, and most unjust, which drawes

The Vulgar by thy Rhet'rick to hard Lawes

Which makes them silly Ones, content to be,

To take up Voluntary Slavery.

And mak'st great Inequalities beside,

Some like to Asses beare, others on Horsback ride.

Peace.

O War, thou cruell Enemy to Life,

Vnquieted Neighbour, breeding alwaies Strife

I the Parent of Learning am, and Arts,

Nurse to Religion, and Comfort to all Hearts.

I am the Guardian, which keepes Vertue safe. (PF, 90-91)

As the guardian of virtue, peace is cast in the poem as something that can vanquish the injustices and concrete harms of war. We can strive for and attain peace, especially when we seek it in other endeavors, like religion, aesthetics, and moral education.

Cavendish does not only prop peace up as the aim for moral action, but she also explicitly repudiates vice as something to be avoided. She writes, "Vices are Vices, no otherwise but that they are Hurtfull or Destructive to Mankind, which makes them Vices, for the Gods Forbid them because of the Evil Effects" (Cavendish [1666] 2003b, p. 207). These are not the words of a thinker who conceives of human states of affairs as having univocal value, but of one who has thought carefully about ways in which people are responsible for goods and harms they reap on each other. Instead, she calls us to think of concrete harms as those which have pragmatic, deleterious effects on the government, and on individuals.

It cannot be maintained, then, that moral categories and values are vacuous for Cavendish. In her ethical and political writings, she remains, as ever, the eccentric scholar, but she is consistent about her beliefs about the abomination of war (and civil war, in particular), and that the political can be debated and can shape human action. Similarly, Cavendish is clear that political and civic harms relate importantly to religious beliefs and experiences. Her political work responds to horrors (Broad and Green 2009), depicts lived experiences of suffering, and is directly tied to the problem of evil. Cavendish writes, for example: "Rationally one would think that God should not take delight in shaven heads, or bare and dirty feet, or cold backs, or hungry stomachs" (Cavendish 1655, pp. 29-30).

If we fashion some systematicity to Cavendish's views on the problem of evil, we will see that Cavendish positions evil firmly in the concrete, in at least two distinct ways. First, moral evil comes about when we choose to do that which we know we ought not to do. It may seem basic for an ethical theory to identify evil with action that goes against what an agent is meant to do morally, but it is significant that Cavendish underscores the fact that immoral action ought not to occur. Karen Detlefsen, for example, highlights this facet of Cavendish's ethics when she points out that, for Cavendish, "We may even willfully and freely deviate from these best guesses (e.g., as did those who fomented the civil war through which Cavendish lived)" (Detlefsen 2009, p. 433), and that when we choose wrongly, injustices occur, and especially limit the ability of women to think for themselves. Concrete evil gains significance in relation to the injustices that result from them.

War is not the only venue through which concrete evil occurs. Instead, Cavendish believed that some of the most harmful incidents occur when women are not allowed to be educated, when they are disallowed from expressing or experiencing civil rights because of political abuses, and when domineering patriarchal domestic and civil rule suppress other freedoms for women. Marriage, 
for example, harbors the possibility that women will be subject to horrors, including, "'the very real threat of death in childbirth ... but women also have to put up with abandonment, abuse, drinking, gambling, not to mention children who turn out to be disgraceful reprobates if they survive (Cavendish 2000, pp. 112-17). The Epilogue proclaims: 'Marriage is a Curse we find/Especially to Women kind (Cavendish 2000, p. 117).'" (Wilson 2007, p. 204). Apart from these potential sources of female suffering, Cavendish sought to "delineate the traits of a fanciful and witty dimension parallel to the masculine dominion of objectivity, where she manifested and realized the inalienable right of a woman to think within the intimacy of her mind and her house." ${ }^{8}$ Freedom and, so, the ability to act morally, depend on, "the independent locus of feminine cognition and enfranchisement" (Mascetti 2008, p. 3), and Cavendish pointed out that many women suffer under domestic and political constraints that prevent them from being able to choose alternate actions. Women, if unfree, are also left unable to ever experience the intellectual and physical goods that are brought about from living a well-chosen path.

Indeed, for Cavendish, most suffering is originally sourced in some intellectual oppression. "We go wrong," Cavendish observes, "either because we are ignorant of the ends which we ought to pursue or because we know what ends we ought to pursue but we willfully deviate from them" (Cavendish 1664a, p. 509f). She was keen to pick out various social settings in which women suffer from being unable to pursue a life of the mind. She even thought women were limited in intellectual pursuits within religious practice: "I thought you had been either Jews, or Turks, because I never perceived any women in your congregations; but what is the reason you bar them from your religious assemblies?" (Cavendish [1666] 2003a, p. 20). Men of her time-who were citizens of the state, and so already had power beyond that of women-suppressed the ability of women to act, behave, and to think freely. When writing to men, Cavendish appeals to natural law (as well as female beauty ${ }^{9}$ ) to argue against the domestic, political, and religious oppression of women. She writes: "It is not only uncivil and ignoble, but unnatural, for men to speak against women and their liberties, for women were made by Nature for men, to be loved, accompanied, assisted, and protected; and if men are bound to love them by Nature, should they restrain them by force: Should they make them slaves, which Nature made to be their dearest associates, their beautifulest objects and sweetest delights?" (Cavendish [1666] 2003a, p. 247). But when writing to women, Cavendish speaks in starker terms about the phenomenological experience of being "Inferior Women": "but alas, men, that are not only our tyrants but our devils, keep us in the hell of subjection, from whence I cannot perceive any redemption or getting out; we may complain, and bewail our condition, but they will not free us; we may murmur and rail against men, yet they regard not what we say" (Cavendish [1666] 2003a, p. 248). The situation of women against men seems without hope, and the tears of women are compared to "puffs of wind" and "fruitless showers" (Cavendish [1666] 2003a, p. 248). Not only do women suffer, but no one takes their suffering seriously. ${ }^{10}$

8 Mascetti (2008, p. 3). Some feminists have worried that Cavendish's reticence to seek to directly abolish systems of patriarchy means that she was less committed to what we would now call a feminist project. Indeed, Cavendish equivocates on issues contemporary feminists would think are important-for example, whether married women really are free; Cavendish at points argues that they are because their natural beauty gives them power over their husbands. Yet at other points, "Cavendish shows a keen awareness of the fact that many early modern women do suffer from a debilitating loss of negative liberty in the patriarchal marriage state," Broad (2014, p. 113). Mascetti replies to this criticism by noting that Cavendish's "philosophical feminism was, therefore, carved out of a conscious and supportive acknowledgment of male hegemony, and not turned into a method of gendered opposition and subversion. The dimension of feminine fancy that she created was innocuously and respectfully parallel to that of male wisdom" (Mascetti 2008, p. 13).

9 Although, some scholars observe the tension with which Cavendish's poems describe the relationship between women (as objects of love) and men (who seek to objectify women through the love act.) Jennifer Low writes, "Cavendish displays both the cruelty and the power relations inherent in the Petrachan ideal through [her] lyric .... By literalizing the trope of lovers' pains, Cavendish brings new life to the convention of the cruel beloved" (Low 1998, p. 160).

10 Cavendish famously defends a monarchy as the proper government to better address civil inequalities. Broad and Green note, "For Cavendish, as for Hobbes, it is crucial that the sovereign's power be simple and undivided. This is the only way in which human beings might gain some unanimity in their opinions about right and wrong: that is, by subordinating their 
This isn't to say that men are the sole oppressors and the only ones that can commit vicious acts. In SL (Cavendish 1664b) (IX), Cavendish entreats an imaginary interlocuter:

though it is easier to do evil than good, for every fool can make an uproar, and a tumultuous disorder, such as the wisest can hardly settle into order again. But Women in State-affairs can do as they do with themselves, they can, and do often make themselves sick, but when they are sick, not well again: So they can disorder a State, as they do their Bodies, but neither can give Peace to th' one, nor Health to th' other; but their restless Minds, and unsatiable Appetites, do many times bring Ruin to the one, and Death to the other.

Women and men can wreak havoc on a government, on each other, and on themselves-and their actions can have consequences such that even the wisest people cannot "settle into order". If we are able to harm each other in ways that escape the healing touch of the wisest among us, we must be compelled to seek knowledge, control appetites, and (ultimately) for Cavendish do what is good.

Cavendish's exhortations against evil and towards good lead us to several conclusions. First, the metaphysical realm is treated differently for Cavendish than the moral order. The content and strictures of morality are purely about human moral action, and so, the moral order is susceptible to be negatively impacted by political and individual actors. But those same actors can bring peace through their moral choices. Cavendish values states of affairs which preserve peace, but not at the cost of vice and enslavement. True peace is obtained when individuals are able to experience civil and domestic rights (especially, of course, if individuals have the benefit of living under a strong, virtuous monarchy). However, peace often does not prevail, and the worst sorts of harm result when it does not. The harms cited by Cavendish are of the sort that contemporary feminist ethicists identify as that worthy of ethical analysis, and which most perniciously serve as evidence against the existence of God: atrocities.

Should the critic argue that the injustices named by Cavendish fall out of the realm of the atrocious harm category, it should be noted that the intellectual injustice Cavendish focuses on is systemic, pernicious, and denigrating, perhaps even more because the harms are not purely physical. Broad and Green observe that, for Cavendish, "Women are not free because they are, quite simply, coerced, threatened, or forced into obedience. In this way, men keep women in the subordinate position of children and fools-human beings without the full use of their reason" (Broad and Green 2009, p. 220). Husbands may have the natural authority to "direct and guide" women, Cavendish suggests, but they err if they interpret that to mean "ruling and governing" and use that interpretation to further limit women's freedom (Boyle 2013, p. 528). Keeping women indentured in the home leads to a continued oppression of women by men in the public sphere.

\section{Free Will and Redemptive Goods}

Margaret Cavendish's commitment to a positive view of moral goods and immoral harms that is grounded in the concrete impinges on the problem of evil in the early modern period, and belies a pragmatic and moral point for Cavendish as a theist: there are lived experiences of suffering and evil that must be made consistent with a loving, relational God. It is difficult to defend God's dual role in preserving justice and divine love. If God shares in our grief, who is responsible for inflicting it? How can there be justice if the innocent bears the punishment of the guilty, and how is justice administered if responsibility for divine suffering is transferred from humankind to God? (Walker 1988, p. 183).

Cavendish provides one explicit and one implicit account of divine perfection that should be called "theodicy": God had to create the world as he did, and concrete moral evil is a part of the world, but it does not mitigate against divine perfection. In $S L$, Cavendish gives one of the most traditional 
philosophical arguments in her corpus, when she argues that human freedom requires that God allow for evil in the world. In this long passage from SL CLXX, for example, Cavendish goes so far as to worry about the salvation of those who give up faith because of the problem of evil, and provides a strikingly traditional free-will defense of the problem of evil:

Fear, for Moral Conscience, said she, is the most Tender Effect of a Fearful Passion, but Divine Conscience is an Effect of Grace, which the Common People hath but little of... I do believe, that the Great Omnipotent God is Good, Wise, Powerful, Knowing, Fore-seeing, and Just, as not to Damn a man for that which he could not possibly know, or for that which Nature made him to do, neither was he Ignorant, as not to Fore-see what Man could, or would do, and if Man could do nothing without Gods Permission, Gods Mercy would not Permit, or Suffer Man to Damn himself, for that would be to Make Man to that End, Knowing it before, as Fore-seeing it, and if he gave Man a Free-Will, that were to give away one of his Attributes, and so to make Man Great, and himself Less, and only to Impower Man to Damn himself; or for God to Make Man, and then Damn him, whereby to shew his Power, would neither stand with God's Justice nor Goodness; but certainly God could shew his Power other wayes, than by Damning those Creatures he Made, or Makes; and that God be as much, if not more Glorified by the Damned as by the Blessed, is but an Odd Belief, that Gods Glory should Arise from Torments, as if God had no other way to be Glorified, this would not Express Justice so much as Severity, if not Cruelty, as first, to Fore-see the Evil, then to make the Creature, and at last to Suffer that Evil, and to Damn the Creature for the Evil ... but most Men have Blasphemous Opinions, as to make God either Cruel, or Ignorant, as not to Fore-know, or else to Make to Damn. (SL, CLXX)

There are a number of distinct points in this text that lend themselves towards theodicy, mostly centered on the concept of divine justice. First, a good God will not punish humans for performing actions that they are unfree to perform, or are non-culpably ignorant in performing. Second, God's mercy is incompatible with a sort of moral necessitarianism. Finally, most people are comfortable thinking blasphemous thoughts about God, namely, that God is perfectly good, all-knowing, and just, but punishes his contingent creation for exercising free will that was given to humanity during creation. By providing a free-will defense, Cavendish provides an argument that is consistent with traditional theodicy in the early modern period. If we want to account for divine perfection and the presence of evil in the world, we need to remember that evil comes when people choose to act in a manner that is contrary to the guidance of the moral law.

Although Cavendish provides traditional justification for the compatibility of divine perfection and evil in the created order, her work also reveals that traditional theodicy is, by itself, insufficient to explain the suffering of the oppressed. Just as contemporary feminism faults traditional theodicy for its abstract conception of evil, Cavendish conceives of evil in concrete, situated terms, and would reject attempts to abstract evil away from the concrete. "Moral evil" is inseparable from actual experiences of suffering in society and in the home. If the purpose of theodicy is to demonstrate (or, more thinly, to explain) how divine perfection is consistent with evil in the world, theodicy ought also to address the plight of those who suffer domestically and socially. ${ }^{11}$ In 21st-century parlance, culpable, preventable atrocities in the world pose a threat to divine perfection, especially divine benevolence. ${ }^{12}$

In the same way that Cavendish's work reveals difficulties with traditional theodicy, it also develops a unique conception of (what we would call today) "redemptive theodicy", as long as "redemption" is understood independent of an eschatology. Cavendish's view of redemption does not

11 See, for example, Anderson (2009) especially Joy (2010).

12 Card defines evil as "reasonably foreseeable intolerable harms produced (maintained, supported, tolerated, and so on) by culpable wrongdoing. So understood, evils have two irreducibly distinct components: a harm component and an agency component" (Card 2002, p. 5). 
rely upon some unknowable, unseen, latter good, and so is not an eschatological event. Redemption is not some ideal that is provided to those who suffer, as a way of placating their anguish through something they can only hope for (but never fully experience until after death, when there will be a complete and just reckoning of the scales). Rather, redemption for Cavendish primarily indicates a civil (rather than specifically spiritual) restoration. Redemption transforms social, religious, and legal systems that have denied women's rights, perpetuated slavery, and waged war, and theodicy that ties the divine concurrence of evil with redemption ought to rely upon a concrete sense of justice (i.e., one that is accessible through the experiences of daily life). If harms are to be eradicated through concrete, just actions, a requirement of any theodicy is that society must be transformed. But, just as redemption is a civic enterprise, instead of a religious one, the transformation of society that must accompany any theodicy must come about by creative human agency.

It might be said that reading Cavendish's demand that redemption for acts of injustice must come through redemptive, restorative human action is simply not theodicy. Such a worry rightly focuses Cavendish's focus on positive human creation in the face of evil. It is true that, compared to contemporary theists, Cavendish provides a thin evaluation of divine culpability for evil (or for good in the world, for that matter). But this is not because she is not doing theodicy, but rather is largely due to her skepticism about what can be known about the nature of God. Cavendish is not a skeptic about whether God exists. She writes: "No part of nature can or does conceive the essence of God, or what God is in himself; but it conceives only, that there is a divine being which is supernatural" (Cavendish [1666] 2003a, p. 17). That God exists is not something to be skeptical about, since the natural order is a created one, but we ought to be reticent to claim to understand anything that transcends the scope of nature. It false to infer from her reluctance to pontificate about the nature of God that Cavendish entirely avoids the problem that evil poses to divine perfection. Cavendish thinks, for instance, that it would be absurd to think that God would permit Satan, "to have such a familiar conjunction, and make such contracts with Man, as to empower him to do mischief and hurt to others, or to foretell things to come, and the like" (Cavendish 1664a, p. 227). She confirms in an earlier PL (Cavendish 1664a) passage (that maps onto the $S L$ theodical text), that:

God's Mercy would not Permit or suffer Man to Damn himself, for that would be to Make Man to that End, Knowing it before, as Fore-seeing it, and if he gave Man a Free-Will, that were to give away one of his Attributes, and so to make Man Great, and himself Less, and only to Empower Man to Damn himself; ... this would not Express Justice so much as severity, if not Cruelty, as first, to Fore-See the Evil, then to make the Creature, and at last to Suffer that Evil, and Damn the Creature of the Evil; neither, said she, can that Rational Part that God hath given me, perceive how it can stand with his Goodness and Mercy, or his Wisdom and Glory, to Suffer more Devils, than to Make Saints.

(Cavendish 1664a, p. 170)

This passage argues, a bit differently than the $S L$ text, that divine goodness would prevent finite human sins to condemn us to eternal damnation. The benevolence of God-characterized here as mercy and justice-is juxtaposed against the concrete results of human evil, such as cruelty and suffering. Of course, there is a hint at a free will defense here as well, but that defense is strongly overshadowed by appeals to divine goodness. It is irrational, Cavendish's character asserts, to conceive of a good and fully wise God that would create humans who could eternally condemn themselves, just as it is irrational to conceive of a good God who could allow his creation to suffer. The interlocuter interjects, not to disagree, but to warn against anthropomorphizing God: "Man is so Presumptuous, as to Assimilize God, as also to Pretend to know what God sayes, making him to Speak like Man; also to Express him to have Passions; but if God be Absolute and Incomprehensible, it is High Presumption to Assimilize God to any Creature; besides, it is absurd and Ridiculous to Compare that which is Incomprehensible, for if he cannot be Conceived, how shall he be Express'd?" Cavendish (1664a, p. 170). If there is a God (and there is, for Cavendish), we cannot know anything 
about his nature. We can merely acknowledge that he is, and that he exists in the manner of perfection. An upshot to this interesting bit of philosophy of religion is that Cavendish thinks that what we can know of God indicates that he would be more interested in fostering the moral development of his creation rather than permitting rampant suffering within it.

A potential critique would come from our inability to know God's nature: if we are ignorant of divine essence (Cavendish 1664a, p. 107), how could Cavendish advocate for a moral response to the problem of evil—whether for humans, who must work towards moral improvement, or for God, who must limit evil in the world? An answer more than likely resides in Cavendish's view of faith, which can ground some substantial claims about God's nature (Cavendish 1664a, pp. 210-211), as well as God's creation. "So, she believes," Karen Detlefsen writes, "in accordance with faith because it is in keeping with Church and Scriptural authority, that God is immaterial, divinely infinite, and perfect" (Cavendish 1664a, pp. 186-187). Yet more regularly, and quite constantly in her mature works, "Cavendish says that God is the author not only of nature's perceptive, knowing capacity and therefore of nature's freedom, but also of nature's self-moving power." (Detlefsen 2009, p. 430)

Although God is the author of nature, Cavendish stops short of concluding that God is the author of moral evil. God creates the conditions under which humans can use their freedom, and his power does not rule the minute details of everyday life, "like as one wheel in a clock turns all the rest" (Cavendish 1666, p. 212). Detlefsen describes the relationship Cavendish sees between nature and God as "interaction through rational suggestion" (Detlefsen 2009, p. 439). If divine perfection morally guides created beings, then evil in the world is mitigated by reforming bad actions (that come, on Cavendish's view, from some false thinking and acting inconsistently with the best guidelines of morality). The hard human work of redeeming evil requires that individuals who perform evil actions, "be improved through good education, gainful employment, and exposure to models of virtue" (Boyle 2006, p. 260). ${ }^{13}$

Cavendish thus provides a redemptive account of evil, in which reformation is realized by transforming evil minds within peaceful society rather than by some heavenly escape from the trappings of the body. There is an original goodness in all people that is masked by the intellectual paternalism of the powerful. When we do the difficult work of opening access to free intellectual pursuits, oppression changes from the inside out. Rather than depending upon some otherworldly eschatology for redemption, Cavendish puts forward a picture in which human action can focus on broadening access to intellectual pursuits for women (and others who are not able to pursue them). Reason affords us the ability to change the intellectual suppression of others: "In Cavendish's scheme, philosophical civility is guaranteed by intellectual governance, a regulatory function she attributes to institutions that foster heterogeneity." (Barnes 2009, p. 54).

\section{Conclusions}

Divine justice, for Cavendish, is preserved when all wrongdoers partake in redemption as a natural part of God's creative order, whose completion is in our perfection. Her redemptive theodicy is grounded in a paradigm that mirrors the contemporary atrocity paradigm, and yet confirms the necessity of moral transformation, especially towards civil and domestic peace. The minimum result is that her work, which has its starting point in concrete, situated evil, and moves out to a defense of divine existence, ought to be considered within the corpus of philosophy of religion. Perhaps, too, the maximum result is a theodicy whose end-participative redemption-is available to all, independent of theistic belief. The accessibility of redemption underscores the normative force of Cavendish's philosophy of religion. The moral law is embedded into the created order, organized according to

13 Unsurprisingly, Cavendish thinks moral transformation can result from a proper authoritative structure within government, "Thus the role of government is not merely to control those with 'rude and wild natures' but to transform them" (Boyle 2006, p. 260). 
the rules of reason, and functions for all people. The cycle of redemption and reformation can bring transformation and healing to the person who experiences and participates in it. Theodicy that ignores concrete evil misses the phenomenological significance of living in a world with pain and suffering. ${ }^{14}$

Conflicts of Interest: The author declares no conflict of interest.

\section{References}

Adams, Marilyn McCord. 1999. Horrendous Evils and the Goodness of God. Ithaca: Cornell University Press.

Adams, Marilyn McCord. 2006. Christ and Horrors. Cambridge: Cambridge University Press.

Anderson, Pamela Sue, ed. 2009. New Topics in Feminist Philosophy of Religion: Contestations and Transcendence Incarnate. Berlin: Springer.

Bar On, Bat-Ami. 2007. Terrorism, Evil, and Everyday Depravity. In Feminist Philosophy and the Problem of Evil. Edited by R. M. Schott. Bloomington: University of Indiana and Hypatia, Inc., pp. 195-205.

Barnes, Diana. 2009. Familiar Epistolary Philosophy: Margaret Cavendish's Philosophical Letters. Parergon 26: 39-64. [CrossRef]

Boyle, Deborah. 2006. Fame, Virtue, and Government: Margaret Cavendish on Ethics and Politics. Journal of the History of Ideas 67: 251-89. [CrossRef]

Boyle, Deborah. 2013. Margaret Cavendish on Gender, Nature, and Freedom. Hypatia 28: 516-32. [CrossRef]

Broad, Jacqueline. 2007. Margaret Cavendish and Joseph Glanvill: Science, religion, and witchcraft. Studies in History and Philosophy of Science 38: 493-505. [CrossRef]

Broad, Jacqueline. 2014. Women on Liberty in Early Modern England. Philosophy Compass 9: 112-22. [CrossRef]

Broad, Jacqueline, and Karen Green. 2009. A History of Women's Political Thought in Europe, 1400-1700. Cambridge: Cambridge University Press, p. 200.

Card, Claudia. 2002. The Atrocity Paradigm. New York: Oxford University Press.

Card, Claudia. 2010. Confronting Evils: Terrorism, Torture, Genocide. Cambridge: Cambridge University Press.

Cavendish, Margaret. 2003a. The Blazing World. In Margaret Cavendish Political Writings. Edited by Susan James. Cambridge: Cambridge University Press. First published 1666.

Cavendish, Margaret. 2003b. Orations of Divers Sorts. In Margaret Cavendish Political Writings. Edited by Susan James. Cambridge: Cambridge University Press. First published 1666.

Cavendish, Margaret. 1653. Poems, and Fancies. London: Text Creation Partnership.

Cavendish, Margaret. 1655. The Worlds Olio. London: Text Creation Partnership.

Cavendish, Margaret. 1664a. Philosophical Letters, or Modest Reflections upon Some Opinions in Natural Philosophy. London: Text Creation Partnership.

Cavendish, Margaret. 1664b. Sociable Letters. London: Text Creation Partnership.

Cavendish, Margaret. 1666. Observations upon Experimental Philosophy, to which is Added, The Description of a New Blazing World. London: Text Creation Partnership.

Cavendish, Margaret. 2000. Paper Bodies: A Margaret Cavendish Reader. Edited by Sara Heller Mendelson and Sylvia Bowerbank. Toronto: Broadview Literary Texts.

Cunning, David. 2016. Cavendish. London: Routledge.

Detlefsen, Karen. 2009. Margaret Cavendish on the Relation between God and World. Philosophy Compass 4: 421-38. [CrossRef]

Hernandez, Jill. 2016. Early Modern Women and the Problem of Evil: Atrocity \& Theodicy. London: Routledge.

Joy, Morny. 2010. Rethinking the 'Problem of Evil' with Hannah Arendt and Grace Jantzen. Dordrecht: Springer.

Low, Jennifer. 1998. Surface and Interiority: Self-Creation in Margaret Cavendish's. The Claspe. Philological Quarterly 77: 149-69.

14 There are feminists and theologians who would disagree, of course, with a redemptive theodicy, whether grounded in abstract or concrete evil. Oppressive paternalistic regimes could, after all, continue their abuses of political power with the promise that their antics are necessary for the project of redemption to occur. Cavendish does not argue that political injustices are justified on the basis of whether they eventually strengthen the character of the person who suffers, but given that they are part of our cache of human experiences, we must then answer the question, "What now?" 
Mascetti, Yaakov. 2008. A 'World of Nothing, but Pure Wit': Margaret Cavendish and the Gendering of the Imaginary. Partial Answers: Journal of Literature and the History of Ideas 6: 1-31. [CrossRef]

Stump, Eleanore. 2010. Wandering in Darkness. Oxford: Oxford University Press.

Walker, Michael. 1988. The Atonement and Justice. Theology 91: 180-83. [CrossRef]

Wilson, Karen Ross. 2007. Marriage and the Problem of Evil in Works by John Milton and Margaret Cavendish. Ph.D. dissertation, University of California-Davis, Davis, CA, USA. 